\title{
The Impact of Income on Democracy Revisited
}

\author{
Yi Che ${ }^{\mathrm{a}}$, Yi Lu ${ }^{\mathrm{b}}$, Zhigang Tao ${ }^{\mathrm{a}}$, and Peng Wang ${ }^{\mathrm{c}}$ \\ ${ }^{a}$ University of Hong Kong \\ b National University of Singapore \\ ${ }^{c}$ Hong Kong University of Science \& Technology
}

May 2012

\begin{abstract}
This paper revisits the important issue of whether economic development promotes democracy by using the system-GMM method, which is superior to the difference-GMM method when dependent variables (democracy in this paper) are highly persistent over time. With the same data set as that of Acemoglu, Johnson, Robinson, and Yared (2008), we find that the system-GMM estimated coefficient of income per capita is positive and highly statistically significant, in sharp contrast to the difference-GMM results reported by Acemoglu, Johnson, Robinson, and Yared (2008). Furthermore, employing the U.S. and Colombia as an example, we find that much of the difference in democracy across countries can be explained by the corresponding difference in income per capita.
\end{abstract}

Keywords: Income, Democracy, System-GMM, Difference-GMM JEL Codes: P16, O10

${ }^{*}$ Corresponding author: Zhigang Tao, Faculty of Business and Economics, The University of Hong Kong, Pokfulam Road, Hong Kong. Tel: 852-2857-8223; Fax: 852-2858-5614; Email: ztao@hku.hk. We would like to thank Gérard Roland (the Editor), and two anonymous referees for their useful comments and suggestions. Financial support from University of Hong Kong and Hong Kong Research Grants Council is greatly acknowledged. 


\section{Introduction}

A proposition of major and perennial interest to both economists and political scientists is whether economic development promotes democracy. Many studies have reported a positive association between income per capita and the degree of democracy (see, for example, Lipset, 1959; Barro, 1997, 1999; Papaioannou and Siourounis, 2008). However, establishing the causal impact of economic development on democracy is challenging, because there could be unobserved factors influencing both economic development and democracy (i.e., the omitted variables issue), and there may also be reverse causality running from democracy to economic development. In a seminal paper, Acemoglu, Johnson, Robinson, and Yared (2008) (AJRY) use the fixed effects specification to account for time-invariant unobserved factors, and surprisingly find no positive and statistically significant relationship between income per capita and democracy.

As the degree of democracy in an economy is highly persistent over time, AJRY (2008) include the lagged value of democracy in their regression analysis. However, in their fixed effects specification, the difference of the lagged democracy is correlated with the difference of the error term, causing biased estimations of the impact of income per capita. To address this problem, AJRY (2008) use the difference-GMM estimation method developed by Arellano and Bond (1991), in which the difference of lagged democracy is instrumented by all the further available lags of democracy. Recent advances in econometrics, however, show that these available lags of democracy only explain a very small portion of the difference of the lagged democracy (i.e., the weak instrument problem; see Staiger and Stock, 1997; Stock and Wright, 2000; Stock, Wright, and Yogo, 2002) when the dependent variable is highly persistent over time. To resolve this weak instrument problem, Arellano and Bover (1995) and Blundell and Bond (1998) develop a new method called the system-GMM in which the difference-GMM equations are stacked by the level equations where the lagged dependent variable is instrumented by the difference of the lagged dependent variable. In a simulation study of the AR(1) model, ${ }^{1}$ Bond (2002) shows that the system-GMM estimation always outperforms the difference-GMM estimation, especially when the dependent variable is highly persistent over time. ${ }^{2}$ Specifically, as shown in Table 1

\footnotetext{
${ }^{1}$ The model specification is $y_{i t}=\alpha y_{i, t-1}+\left(\eta_{i}+v_{i t}\right)$, where $i$ represents the panel unit; $t$ represents time; $\eta_{i}$ is the panel fixed effect; and $v_{i t}$ is the error term.

${ }^{2}$ Many recent empirical studies have shown that the system-GMM estimator performs better than the difference-GMM estimator; see, for example, Blundell and Bond (2000), Bobba and Coviello (2007), Castello-Climent (2008), Roodman (2009a), and Aslaksen (2010).
} 
(copied from Table 2 of Bond, 2002), the difference-GMM estimate of $\alpha$ is 0.484 (or 0.226 ) when the true value is 0.8 (or 0.9 ), whereas the corresponding system-GMM estimate is 0.810 (or 0.941).

Democracy is indeed highly persistent over time. In Table 2, we present various estimation results of the first-order auto-regression of democracy. The OLS estimated coefficient is 0.866 , which is usually considered the upper bound, whereas the panel fixed effect estimated coefficient is 0.419 , which is often considered the lower bound. The most valid estimate is 0.817 obtained from the $t-3$ system-GMM estimation, as it satisfies the identification assumptions implied by the insignificant Hansen $\mathrm{J}$ test and the insignificant difference Hansen $\mathrm{J}$ test. Because of the highly persistent nature of democracy (i.e., with the $\mathrm{AR}(1)$ coefficient being 0.817 ), the coefficient of the lagged democracy in the AJRY (2008) difference-GMM estimation is only weakly identified and biased, causing the estimated coefficient of income per capita to be biased or even misleading. In this paper, we use the system GMM estimation method to revisit the impact of income per capita on democracy with the same data set as that employed by AJRY (2008) (downloaded from the AER web site).

We find that under the system-GMM estimation, the estimated coefficient of income per capita becomes positive and highly statistically significant, in sharp contrast to the results AJRY (2008) obtain from the difference-GMM method. We then conduct a series of robustness checks: five exercises mirroring those of AJRY (2008) (an alternative measure of democracy, different sub-samples, additional controls, external instrumental variables for income per capita, and longer sample periods and longer time intervals for variable measurement), one exercise the same as that conducted by AJRY (2009) (differential impacts across countries with different initial degrees of democracy), one exercise similar to that of Boix (2011) (different sample periods), one exercise including the additional controls used by Boix and Stokes (2003), Boix (2011), and Miller (forthcoming), and a new exercise (extending the analysis to more recent years). In all these exercises, we find that the coefficient of income per capita is always positive and statistically significant. As a further robustness check, we follow AJRY (2008) in calculating the extent to which our estimation results explain variations in the degree of democracy across countries. Using Colombia as an example, we find that if we elevate income per capita in Colombia to the level of the United States in 2000, our estimation results explain almost all the difference in democracy between these two countries. Overall, this study lends strong support to the modernization hypothesis that economic development promotes democracy (Lipset, 1959).

Several other recent studies have challenged the robustness of the results of AJRY (2008). Boix (2011) overturns the main results of AJRY (2008) 
by extending the data to the early nineteenth century, when hardly any countries were democratic, and by adopting a broader theory of development and international relations. Benhabib, Corvalan, and Spiegel (2011) also re-establish the positive impact of development on democracy by utilizing newer income data and using estimation methods to deal with the problem of measures of democracy being censored. Our paper differs from these two studies by using the same data sets as those employed by AJRY (2008), but we reverse the results of AJRY (2008) by adopting the system GMM estimation method, which is considered more suitable than the panel fixed effects estimation or difference-GMM estimation method when the dependent variable (i.e., democracy in this paper) is highly persistent over time.

Our paper is also related to the literature regarding the exogenous theory of democracy (i.e., that development has a positive impact on the stability of a democratic country) versus the endogenous theory of democracy (i.e., that development has a positive impact on the transition of an autocratic country to a democratic one). Przeworski and Limongi (1997) and Przeworski, Alvarez, Cheibub, and Limongi (2000) find that development helps democratic countries become less likely to revert to autocracy (i.e., providing support for the exogenous theory of democracy), but it has a limited effect on the democratization of autocratic countries (i.e., no supporting the endogenous theory of democracy). Boix and Stokes (2003), however, find evidence supporting both the exogenous and endogenous theories of democracy by both extending the data to the early nineteenth century and including more control variables. ${ }^{3}$ Similar to Boix and Stokes (2003), we offer evidence supporting both the endogenous and exogenous theories of democracy by adopting the system-GMM estimation method to examine the same data set as that used by AJRY (2008, 2009), and the extended data set used by Boix and Stokes (2003) and Boix (2011).

The rest of the paper is organized as follows. Section 2 discusses the data set and model specifications employed for empirical analysis. Section 3 presents our empirical findings. The paper concludes in Section 4.

\footnotetext{
${ }^{3}$ Miller (2011) further elaborates on why the endogenous theory of democracy may not work. Specifically, as income per capita increases, the probability of a social uprising in an autocratic country is likely to decrease, but the chance of a transition to democracy in case of a social uprising would increase. Treisman (2011) shows that the positive impact of economic development on democracy is more pronounced in the medium run (10 to 20 years), which explains why even dictators may still focus on development in the short run, as it helps them to entrench themselves in power.
} 


\section{Data and Model Specification}

The data set used in this paper is the same as that examined by AJRY (2008) (downloaded from the American Economic Review web site ${ }^{4}$ ). The main measure of democracy is the Freedom House Political Rights Index ${ }^{5}$ augmented by Bollen's data. ${ }^{6}$ As a robustness check, we use the Composite Polity Index ${ }^{7}$ from the Polity IV project as an alternative measure of democracy. Both the Freedom House measure of democracy and the Polity measure of democracy are normalized to $[0,1]$, with a higher value indicating a higher degree of democracy. Information about income per capita comes from the Penn World Table for the post-war period and from the study of Maddison (2010) for the pre-war period beginning in 1820.

Following AJRY (2008), we use a dynamic panel data model to investigate the causal impact of income per capita on democracy:

$$
d_{i t}=\alpha d_{i t-1}+\gamma y_{i t-1}+X_{i t-1}^{\prime} \beta+\mu_{t}+\delta_{i}+\varepsilon_{i t},
$$

where $d_{i t}$ is the degree of democracy for country $i$ in period $t ; d_{i t-1}$ is the lagged democracy variable used to account for the persistence of democracy over time; $y_{i t-1}$, the main variable of interest in this study, is the lagged log income per capita; $X_{i t-1}$ is a vector of control variables; $\mu_{t}$ denotes the unobserved time effect controlling for common shocks originated from macroeconomic, political, or technological sources; $\delta_{i}$ is the fixed effect which controls for the unobserved time-invariant country-specific characteristics; and $\varepsilon_{i t}$ is the error term. To account for possible heteroskedasticity, standard errors are clustered at the country level.

To deal with the correlation between $\delta_{i}$ and $d_{i t-1}$ in (1), a first-difference transformation can be used to purge the country fixed effect $\delta_{i}$ :

$$
\Delta d_{i t}=\alpha \Delta d_{i t-1}+\gamma \Delta y_{i t-1}+\Delta X_{i t-1}^{\prime} \beta+\Delta \mu_{t}+\Delta \varepsilon_{i t},
$$

where $\Delta$ is the first-difference operator, e.g., $\Delta d_{i t}=d_{i t}-d_{i t-1}$. Because $\operatorname{Cov}\left(\Delta d_{i t-1}, \Delta \varepsilon_{i t}\right) \neq 0$ due to the fact that $d_{i t-1}$ is a function of $\varepsilon_{i t-1}$, the OLS estimation of (2) produces a biased estimate of $\alpha$, and as a consequence, the estimate of $\gamma$ - the main parameter of interest - is also biased.

\footnotetext{
${ }^{4}$ Web site: http://www.aeaweb.org/issue.php?journal=AER\&volume $=98 \&$ issue $=3$

${ }^{5}$ The Freedom House Political Rights Index ranges from 1 to 7 with a lower value indicating a higher degree of democracy. As the first year of the Freedom House Political Rights Index is 1972, AJRY (2008) use the value of democracy in 1972 for that of 1970 in their five-year interval analysis.

${ }^{6}$ Bollen's data allow us to extend the five-year interval analysis from 1970 to 1950.

${ }^{7}$ The Composite Polity Index ranges from -10 to 10 , with a higher value indicating a higher degree of democracy.
} 
For the consistent estimation of (2), Arellano and Bond (1991) use the difference-GMM method first proposed by Holtz-Eakin, Newey, and Rosen (1988) in which $d_{i t-2}$ and all the further available lags are used as instruments for $\Delta d_{i t-1}$ given there is no second-order serial correlation in $\Delta \varepsilon_{i t}$. The validity of the proposed instruments can be justified by assuming $E\left(\varepsilon_{i t}\right)=$ $E\left(\varepsilon_{i t} d_{i t-j}\right)=0$ for $j=1,2, \ldots t-1$. This corresponds to the following orthogonality condition for (2):

$$
E\left[A_{i}^{\prime} \Delta \Gamma_{i}\right]=0
$$

where $\Delta \Gamma_{i}=\left(\Delta \varepsilon_{i 3}, \Delta \varepsilon_{i 4}, \ldots, \Delta \varepsilon_{i T}\right)^{\prime}$ and

$$
A_{i}=\left[\begin{array}{ccccccc}
d_{i 1} & 0 & 0 & \ldots & 0 & \ldots & 0 \\
0 & d_{i 1} & d_{i 2} & \ldots & 0 & \ldots & 0 \\
. & . & . & \ldots & . & \ldots & . \\
0 & 0 & 0 & \ldots & d_{i 1} & \ldots & d_{i T-2}
\end{array}\right]
$$

Arellano and Bond (1991) suggest using the AR(2) test to check whether there is any second-order serial correlation of $\Delta \varepsilon_{i t}$, and recommend using the Hansen $\mathrm{J}$ test to check for possible violation of the orthogonality condition (3).

However, as pointed out in the Introduction, the difference-GMM method suffers from a severe weak instrument problem when the dependent variable is highly persistent over time. This renders both point estimates and hypothesis tests unreliable (Staiger and Stock, 1997; Stock and Wright, 2000; Stock, Wright and Yogo, 2002). Arellano and Bover (1995) and Blundell and Bond (1998) argue that when the dependent variable is highly persistent over time, the difference of the lagged dependent variable has more explanatory power for the lagged dependent variable than that of the available lags of the dependent variable for the difference of the lagged dependent variable. Hence, they propose augmenting the difference-GMM method with the original level equation (1) in which the lagged first-differenced dependent variable is used as the instrument for the lagged dependent variable. This brings a set of additional orthogonality conditions as follows:

$$
E\left[\Delta d_{i t-1}\left(\delta_{i}+\varepsilon_{i t}\right)\right]=0,
$$

the validity of which can be tested by the difference Hansen J test as proposed by Arellano and Bover (1995) and Blundell and Bond (1998). This method is referred to as the "system-GMM". Given that the degree of democracy in a country is highly persistent over time, we plan to revisit the impact of income per capita on democracy using the system-GMM method. 
It is worth noting that as the instrument count grows with the time dimension $T$, the Hansen $\mathrm{J}$ test for the orthogonality condition (3) or the difference Hansen $\mathrm{J}$ test for the orthogonality condition (4) might suffer from notable size distortion as documented by Andersen and Sorensen (1996), Bowsher (2002), and Roodman (2009b). Roodman (2009b) also discusses other symptoms of instrument proliferation studied in the literature such as overfitting endogenous variables, imprecise estimates of the GMM optimal weighting matrix, and bias in two-step standard errors. Extensive simulation studies conducted by Roodman (2009b) suggest that collapsing instruments, a way to reduce the instrument count, tends to mitigate finite sample bias and greatly increase the ability of the Hansen $\mathrm{J}$ and difference Hansen $\mathrm{J}$ tests to detect violation of orthogonality conditions. When reporting our empirical results, we follow this practice by adding the estimates obtained from collapsing instruments.

\section{Empirical Findings}

\subsection{Main Results}

Columns 1-2 of Table 3 summarize our system-GMM estimation results regarding the impact of income per capita on democracy (i.e., the Freedom House measure of democracy) for the 1960-2000 period, ${ }^{8}$ where both the dependent and independent variables are measured over a five-year interval. ${ }^{9}$ For ease of comparison, the results from the pooled OLS, panel fixed effect and difference-GMM estimations are copied from those of AJRY (2008) in Columns 3-5 of Table 3.

As shown in Column 3, the pooled OLS estimation gives a positive and statistically significant estimated coefficient of income per capita, consistent with the findings of Barro $(1997,1999)$. However, as discovered by AJRY (2008), the coefficient of income per capita becomes statistically insignificant, but positive, once the country fixed effects are controlled for (Column 4), and it becomes significantly negative under the difference-GMM estimation (Column 5). Interestingly, we find that the estimated coefficient of income per capita reverts to a positive and highly statistically significant value under the system-GMM estimation (Column 1).

\footnotetext{
${ }^{8}$ For the details of the data and the construction of variables, please see AJRY (2008).

${ }^{9}$ We use the one-step GMM estimation adopted by AJRY (2008) to make our results comparable with theirs, though the results from the two-step GMM estimation with small sample correction (Windmeijer, 2005) are qualitatively the same (available upon request). We also follow AJRY (2008) in using a double lag to instrument income per capita in the GMM estimation.
} 
Our system-GMM estimation is valid, as the insignificance of the $\operatorname{AR}(2)$ test result implies no second-order serial correlation of the error term, the insignificance of the Hansen $\mathrm{J}$ test result suggests the satisfaction of orthogonality condition (3), and the insignificance of the difference Hansen $\mathrm{J}$ test result implies the satisfaction of orthogonality condition (4). More importantly, the estimated coefficient of lagged democracy (0.574) is rather high, lying well between the lower limit of fixed effects estimate (0.379) and the upper limit of pooled OLS estimate (0.706). The high persistence of the degree of democracy in a country over time is expected to lend more credence to the results of the system-GMM estimation than it is to those of the difference-GMM estimation (Bond, 2002).

As a way of checking whether or not our system-GMM estimation results make sense, we conduct a counterfactual analysis investigating whether variations in the degree of democracy across countries can be explained by their differences in income per capita. We follow AJRY (2008) by comparing the U.S. with Colombia as an illustration. The first two pillars in Figure 1 are the democracy scores (measured by the Freedom House index) of the U.S. and Colombia in 2000, respectively. Given that our estimated coefficient of income per capita is 0.102 (Column 1 of Table 3), the short-run impact of income per capita on democracy in Colombia would be an increase of $(10.41-8.59) \times 0.102=0.187$ if Colombia's log income per capita were lifted from 8.59 to the level of the U.S. (i.e., 10.41). The long-run impact of income per capita on democracy in Colombia would be an increase of $0.187 \div(1-0.574)=0.438$, where 0.574 is the coefficient of the lagged democracy (Column 1 of Table 3 ). These two degrees of democracy for Colombia are presented in pillars 3 and 4 of Figure 1, respectively. It is interesting to note that the height of pillar 4 is almost the same as that of pillar 1, indicating that the difference in income per capita between Colombia and the United States explains most of the difference in democracy between the two countries.

To check the robustness of our system-GMM estimates, we also report results from the system-GMM estimation with collapsing instruments, aimed at alleviating the instrument proliferation problem in the system-GMM estimation. Using collapsing instruments barely changes either the magnitude or statistical significance of the system-GMM estimates (Column 2 of Table 3). Meanwhile, the system-GMM estimates with collapsing instruments pass the various specification tests: the Hansen $\mathrm{J}$ test, the difference Hansen $\mathrm{J}$ test, and the $\operatorname{AR}(2)$ test. 


\subsection{Robustness checks}

In the following section, we conduct a series of robustness checks: five exercises the same as those conducted by AJRY (2008) (an alternative measure of democracy, different sub-samples, additional controls, external instrumental variables for income per capita, and longer sample periods and longer time intervals for variable measurement), one exercise the same as that employed by AJRY (2009) (differential impacts across countries with different initial degrees of democracy), one exercise similar to that of Boix (2011) (different sample periods), one exercise including the additional controls used by Boix and Stokes (2003), Boix (2011) and Miller (forthcoming), and a new exercise (extending the analysis to more recent years).

Alternative measure of democracy. In the main analysis above, we use the Freedom House measure of democracy augmented by Bollen's data, which cover only the post-1950 period. As a robustness check, we use an alternative measure of democracy, Polity IV, which provides information for all independent countries starting in 1800. The system-GMM estimation results obtained using the Polity measure of democracy are reported in Column 1 of Table 4 . We find a positive and statistically significant coefficient of income per capita. This result is consistent with our earlier system-GMM results (Column 1 of Table 3) and contrast sharply with the results of the panel fixed effects and difference-GMM estimations reported by AJRY (2008).

Different sub-samples. In Columns 2-3 of Table 4, we present our system-GMM estimation results for two sub-samples to address two possible sampling concerns in line with the approach of AJRY (2008). First, we focus on a balanced sample of countries from 1970 to 2000 to make sure our results are not affected by the entry and exit of countries during the sample period. Second, we focus on a sub-sample excluding former socialist countries to alleviate the concern that our results could be affected by the inclusion of these countries, which experienced a surge in democracy yet underwent significant economic decline in the late 1980s and the 1990s. In both subsamples, the system-GMM estimated coefficients of income per capita are positive and statistically significant, consistent with our main findings but in contrast to the negative and statistically significant coefficients reported by AJRY (2008).

Additional Controls. Next, we investigate whether our results are affected by some covariates that may affect both income per capita and democracy. Specifically, we include in Column 4 of Table 4 the logarithm of population, age structure, and education in line with AJRY (2008), and we further include in Column 5 of Table 4 urbanization, the number of previous democratic breakdowns, international order, and the growth rate 
following the approach of Boix and Stokes (2003), Boix (2011) and Miller (forthcoming). Clearly, the coefficient of income per capita obtained with the inclusion of these additional controls is positive and statistically significant in all instances in line with our main analysis. Among these additional controls, we find that education has a positive and statistically significant impact on democracy, consistent with findings in the literature (Barro, 1999; Glaeser, La Porta, Lopez-De-Silanes and Shleifer, 2004; Glaeser, Ponzetto and Shleifer, 2007) but in sharp contrast to the results of the fixed effect and difference-GMM estimations reported by AJRY (2008).

External instruments for income. Thus far, we have instrumented income per capita by its double lag as do AJRY (2008). As a further robustness check, we follow AJRY (2008) in using two distinct external instruments for income per capita: the past savings rate and predicted income based on the trade-share-weighted average income of other countries. ${ }^{10}$ Our systemGMM estimation results are reported in Columns 6-7 of Table 4. Again, we find that the system-GMM estimated coefficients of income per capita are positive and significant, in contrast to the negative and significant coefficients under the corresponding difference-GMM estimations reported by AJRY (2008).

Longer sample periods and longer time intervals for variable measurement. Thus far, we have used the data employed by AJRY (2008), which cover the 1950-2000 period. As more data have since become available, we first extend the sample period to 2010. Specifically, we obtain data on income per capita from Penn World Table 7.0 $0^{11}$ and on democracy from Freedom House. ${ }^{12}$ This enables us to include more countries in the analysis, yielding an increase of 47 countries in the system-GMM estimation. This allows us to make sure our earlier results are not driven by the particular sample period and the particular set of countries examined. It is reassuring to find that income per capita continues to have a positive and statistically significant impact on democracy in the system-GMM estimation (Column 8 of Table 4).

Second, using the Polity IV measure of democracy enables us to further extend the first year of the sample period from 1950 to 1820, while data on income per capita from 1820 to 1950 are obtained from the study of Maddison (2010). ${ }^{13}$ In Column 1 of Table 5, we report the system-GMM estimation results for the 1820-2008 sample period using a 5-year interval

\footnotetext{
${ }^{10}$ For the rationales of these two instruments, please refer to the original paper of AJRY (2008).

${ }^{11}$ Web site: http://pwt.econ.upenn.edu/php_site/pwt_index.php

${ }^{12}$ Web site: http://www.freedomhouse.org/

${ }^{13}$ Web site: http://www.ggdc.net/MADDISON/oriindex.htm
} 
as in our main analysis. Clearly, the results are qualitatively the same as those reported earlier, implying our results are robust for the longer sample period. Moreover, in Columns 2-3 of Table 5, we investigate the impact of income per capita on democracy using longer time intervals of 10 and 25 years, respectively. The coefficient of income per capita remains positive and statistically significant. Our results lend further support to Boix (2011), who highlights the importance of including the earlier waves of democratization in investigating the impact of income per capita on democracy. ${ }^{14}$ Moreover, the coefficients are much larger than those obtained in the shorter time interval (i.e., the five-year interval), presumably because greater changes can be detected over longer time intervals of variable measurement, similar to what Treisman (2011) reports.

Different time periods. As noted by Boix (2011), democratization has occurred in waves over the last 200 years. It is therefore possible that the impact of income per capita on democracy may differ in different time periods. To examine this possibility, we divide our sample into five time periods - 1820-1849 (pre-first wave of democracy), 1850-1920 (first wave), 1920-1944 (reversal), 1945-1975 (second wave and reversal), and 1976-2008 (third wave of democratization) - in a manner similar to Boix (2011). The system-GMM estimation results are summarized in Table 6. It is clear that other than during the first time period (1820-1849), the coefficient of income per capita on democracy is always positive and statistically significant, consistent with our aforementioned main results. ${ }^{15}$

Differential impacts across countries with different initial degrees of democracy. There is a debate regarding whether the impact of income per capita on democracy may depend on the initial degree of democracy (see, for example, Przeworski and Limongi, 1997; Przeworski, Alvarez, Cheibub and Limongi, 2000; Boix and Stokes, 2003). Specifically, for a country with a low initial degree of democracy, an increase in income per capita may facilitate its transition to democracy (called the endogenous theory in the literature). Meanwhile, for a country with a high initial degree of democracy, an increase in income per capita may make it less likely to revert to dictatorship (called the exogenous theory in the literature).

To investigate the validity of these two theories, we modify (1) as follows (i.e., in the same manner as AJRY (2009))

\footnotetext{
${ }^{14}$ Boix (2011) points out that few countries had democratic systems in the first half of the nineteenth century, and including this period in the statistical analysis is crucial to revealing the impact of income per capita on democracy.

${ }^{15}$ The coefficient of income per capita for the first period is also positive, but insignificant, presumably because of the small sample size (i.e., 24 observations).
} 


$$
d_{i t}=\alpha d_{i t-1}+\gamma^{E N D O} \tau_{i t-1} y_{i t-1}+\gamma^{E X O}\left(1-\tau_{i t-1}\right) y_{i t-1}+\mu_{t}+\delta_{i}+\varepsilon_{i t}
$$

where $\tau_{i t-1}$ is a dummy variable equal to 1 if $d_{i t-1}$ is below the sample mean and 0 otherwise; $\gamma^{E N D O}$ captures the effect of income per capita on democracy for countries in which the degree of democracy is below the sample mean (the exogenous theory); and $\gamma^{E X O}$ captures the effect of income per capita on democracy for countries in which the degree of democracy is above the sample mean (the endogenous theory). The system-GMM estimation results are reported in Table 7 . It is found that $\gamma^{E X O}$ is positive and statistically significant, supporting the exogenous theory and consistent with the findings of Przeworski and Limongi (1997) and Boix and Stokes (2003). Meanwhile, $\gamma^{E N D O}$ is also positive and statistically significant, supporting the endogenous theory and consistent with the findings of Boix and Stokes (2003). Moreover, these results are consistent with our aforementioned results, but are in sharp contrast to those reported by AJRY (2009).

Collapsed system-GMM. Recall that in the main analysis (Section 3.1) we use collapsing instruments as a check of the validity of the systemGMM estimation. Here, we conduct a similar analysis for all the above robustness checks and find that our results are qualitatively the same. For details, see Tables A, B, and $\mathrm{C}$ of the Appendix.

It is interesting to note that there are certain cases where the specification tests (i.e., the Hansen J test and the difference Hansen J test) fail. However, these are also the cases where the difference-GMM estimations also fail the specification test (i.e., the Hansen J test). Moreover, the estimated coefficient of income per capita obtained using the system-GMM estimation with the full instrument set is qualitatively the same as those obtained using collapsing instruments. These results suggest that our system-GMM estimation results are not affected by the instrument proliferation problem.

\section{Conclusion}

The seminal work of AJRY (2008) on the unimportance of income per capita to democracy has caused quite a stir in the economics and political science community. The identification of AJRY (2008) relies on the use of the difference-GMM method; however, this method suffers from the weak instrument problem when the dependent variable (i.e., the degree of democracy) is highly persistent over time. In this paper, we revisit the impact of income per capita on democracy using the system-GMM method, which is developed to correct the weak instrument problem encountered by the difference-GMM 
method. Using the same data set as that employed by AJRY (2008), we find that income per capita has a positive and highly significant impact on democracy, thus reversing their results. Given that it is impossible to conduct a controlled experiment on this topic, studies have to rely on the examination of non-randomized, secondary data with somewhat imperfect estimation methodologies. Nonetheless, the results we obtain using the system-GMM method - a method arguably better than its difference-GMM alternative for dealing with the potential endogeneity problem in panel data - add more weight for acceptance of the modernization theory, i.e., that economic development promotes democracy.

\section{References}

[1] Acemoglu, Daron, Simon Johnson, James A. Robinson, and Pierre Yared. 2008. Income and Democracy. American Economic Review, 98(3): 808-842.

[2] Acemoglu, Daron, Simon Johnson, James A. Robinson, and Pierre Yared. 2009. Reevaluating the Modernization Hypothesis. Journal of Monetary Economics, 56(8): 1043-1058.

[3] Andersen, Torben G. and Bent E. Sorensen. 1996. GMM Estimation of a Stochastic Volatility Model: a Monte Carlo Study. Journal of Business and Economic Statistics, 14(3): 328-352.

[4] Arellano, Manuel and Stephen Bond. 1991. Some Tests of Specification for Panel Data: Monte Carlo Evidence and An Application to Employment Equations. Review of Economic Studies, 58(2): 277-297.

[5] Arellano, Manuel and Olympia Bover. 1995. Another Look at the Instrumental Variable Estimation of Error-components Models. Journal of Econometrics, 68: 29-51.

[6] Aslaksen, Silje. 2010. Oil and Democracy: More than a Cross-Country Correlation? Journal of Peace Research, 47(4): 421-431.

[7] Barro, Robert J. 1997. Determinants of Economic Growth: A CrossCountry Empirical Study. Cambridge: MIT Press.

[8] Barro, Robert J. 1999. Determinants of Democracy. Journal of Political Economy, 107: 158-183. 
[9] Benhabib, Jess, Alejandro Corvalan, and Mark M. Spiegel. 2011. Reestablishing the Income-democracy Nexus. NBER Working Paper 16832 .

[10] Blundell, Richard and Stephen Bond. 1998. Initial Conditions and Moment Restrictions in Dynamic Panel Data Models. Journal of Econometrics, 87: 115-143.

[11] Blundell, Richard and Stephen Bond. 2000. GMM Estimation with Persistent Panel Data: an Application to Production Functions. Econometric Review, 19(3): 321-340.

[12] Bobba, Matteo and Decio Coviello. 2007. Weak Instruments and Weak Identification, in Estimating the Effects of Education, on Democracy. Economic Letters, 96: 301-306.

[13] Boix, Carles and Susan C. Stokes. 2003. Endogenous Democratization. World Politics, 55(4): 517-549.

[14] Boix, Carles. 2011. Democracy, Development, and the International System. American Political Science Review, 105(4): 809-828.

[15] Bond, Stephen R. 2002. Dynamic Panel Data Models: a Guide to Micro Data Methods and Practice. Portuguese Economic Journal, 1: 141-162.

[16] Bowsher, Clive G. 2002. On Testing Overidentifying Restrictions in Dynamic Panel Data Models, Economics Letters, 77: 211-220.

[17] Castello-Climent, Amparo. 2008. On the Distribution of Education and Democracy. Journal of Development Economics, 87: 179-190.

[18] Glaeser, Edward L., Rafael La Porta, Florencio Lopez-De-Silanes, and Andrei Shleifer. 2004. Do Institutions Cause Growth? Journal of Economic Growth, 9: 271-303.

[19] Glaeser, Edward L., Giacomo A.M. Ponzetto, and Andrei Shleifer. 2007. Why Does Democracy Need Education? Journal of Economic Growth, 12: 77-99.

[20] Holtz-Eakin, Douglas, Whitney Newey, and Harvey S. Rosen. 1988. Estimating Vector Autoregressions with Panel Data. Econometrica, 56(6): 1371-1395. 
[21] Lipset, Seymour Martin. 1959. Some Social Requisites of Democracy: Economic development and Political Legitimacy. American Political Science Review, 53(1): 69-105.

[22] Maddison, Angus. 2010. Statistics on World Population, GDP and Per Capita GDP, 1-2008 AD.

[23] Miller, Michael K. Forthcoming. Economic Development, Violent Leader Removal, and Democratization. American Journal of Political Science.

[24] Papaioannou, Elias and Gregorios Siourounis. 2008. Economic and Social Factors Driving the Third Wave of Democratization. Journal of Comparative Economics, 36: 365-387.

[25] Przeworski, Adam and Fernando Limongi. 1997. Modernization: Theories and Facts. World Politics, 49(2): 155-183.

[26] Przeworski, Adam, Michael E. Alvarez, Jose Antonio Cheibub, and Fernando Limongi. 2000. Democracy and Development: Political Institutions and Well-being in the World, 1950-1990. Cambridge: Cambridge University Press.

[27] Roodman, David. 2009a. How to Do Xtabond2: an Introduction to Difference and System GMM in Stata. Stata Journal, 9(1): 86-136.

[28] Roodman, David. 2009b. A Note on the Theme of Too Many Instruments. Oxford Bulletin of Economics and Statistics, 71(1): 0305-9049.

[29] Staiger, Douglas and James H. Stock. 1997. Instrumental variables regression with weak instruments. Econometrica, 65(3): 557-586.

[30] Stock, James H. and Jonathan H. Wright. 2000. GMM with Weak Identification. Econometrica, 68(5): 1055-1096.

[31] Stock, James H., Jonathan H. Wright and Motohiro Yogo. 2002. A Survey of Weak Instruments and Weak Identification in Generalized Method of Moments. Journal of Business and Economic Statistics, 20(4): 518529.

[32] Treisman, Daniel. 2011. Income, Democracy, and the Cunning of Reason. NBER Working Paper 17132.

[33] Windmeijer, Frank. 2005. A Finite Sample Correction for the Variance of Linear Efficient Two-step GMM Estimators. Journal of Econometrics, 126: $25-51$. 
Table 1: Simulation Results

\begin{tabular}{lllll}
\hline \hline $\mathrm{N}$ & $\alpha$ & $\begin{array}{l}\text { Fixed Effects } \\
(1)\end{array}$ & $\begin{array}{l}\text { Difference-GMM } \\
(2)\end{array}$ & $\begin{array}{l}\text { System-GMM } \\
(3)\end{array}$ \\
\hline 100 & 0.5 & -0.0037 & 0.464 & 0.510 \\
& & $(0.070)$ & $(0.267)$ & $(0.133)$ \\
& 0.8 & 0.134 & 0.484 & 0.810 \\
& & $(0.072)$ & $(0.822)$ & $(0.162)$ \\
& 0.9 & 0.191 & 0.226 & 0.941 \\
& & $(0.073)$ & $(0.826)$ & $(0.156)$ \\
\hline
\end{tabular}

Note: This table is copied from Table 2 of Bond (2002). There are four periods and 1000 replications in the simulation. $\mathrm{N}$ is the number of panel units in the panel data. $\alpha$ is the true persistent rate. Columns 1-3 report the mean of the 1000 replications for fixed effect, difference-GMM and system-GMM results, respectively. The standard errors are reported in the parentheses. For more information, please refer to the original paper (Bond, 2002). 
Table 2: First-order Auto-regression of Democracy

\begin{tabular}{|c|c|c|c|c|c|}
\hline & \multicolumn{5}{|c|}{\begin{tabular}{|l} 
Dependent Variable is Democracy ${ }_{t}$ (Freedom House Measure) \\
\end{tabular}} \\
\hline & $\begin{array}{l}\text { OLS } \\
\text { (1) }\end{array}$ & $\begin{array}{l}\text { Fixed } \\
\text { Effects } \\
(2)\end{array}$ & $\begin{array}{l}\text { Difference-GMM } \\
\mathrm{t}-2 \\
(3)\end{array}$ & $\begin{array}{l}\text { System-GMM } \\
\mathrm{t}-2 \\
(4)\end{array}$ & $\begin{array}{l}\text { System-GMM } \\
t-3 \\
(5)\end{array}$ \\
\hline Democracy $_{\mathrm{t}-1}$ & $\begin{array}{c}0.866 * * * \\
(0.018) \\
\end{array}$ & $\begin{array}{c}0.419 * * * \\
(0.047)\end{array}$ & $\begin{array}{c}0.519 * * * \\
(0.081)\end{array}$ & $\begin{array}{c}0.676 * * * \\
(0.049)\end{array}$ & $\begin{array}{c}0.817 * * * \\
(0.055)\end{array}$ \\
\hline Hansen J Test & & & 0.06 & 0.04 & 0.10 \\
\hline Difference Hansen J Test & & & & 0.21 & 0.18 \\
\hline $\operatorname{AR}(1)$ Test & 0.00 & 0.75 & 0.00 & 0.00 & 0.00 \\
\hline AR (2) Test & 0.85 & 0.02 & 0.33 & 0.26 & 0.26 \\
\hline Observations & 1232 & 1232 & 1110 & 1232 & 1232 \\
\hline Countries & 194 & 194 & 167 & 194 & 194 \\
\hline
\end{tabular}

Note: ${ }^{* * *}$ represents the statistical significance at $1 \%$ level. Standard errors clustered at the country level are reported in parentheses. 
Table 3: Main Results

\begin{tabular}{|c|c|c|c|c|c|}
\hline & \multicolumn{5}{|c|}{ Dependent Variable is Democracy (Freedom House Measure) $^{2}$} \\
\hline & $\begin{array}{l}\text { System-GMM } \\
\text { (1) } \\
\end{array}$ & $\begin{array}{l}\text { System-GMM } \\
\text { Collapsing } \\
\text { Instruments } \\
(2)\end{array}$ & OLS & $\begin{array}{l}\text { Fixed } \\
\text { Effects } \\
(4) \\
\end{array}$ & Difference-GMM \\
\hline Democracy $_{\mathrm{t}-1}$ & $\begin{array}{l}0.574 * * * \\
(0.061)\end{array}$ & $\begin{array}{l}0.559 * * * \\
(0.069)\end{array}$ & $\begin{array}{l}0.706 * * * \\
(0.035)\end{array}$ & $\begin{array}{c}0.379 * * * \\
(0.051)\end{array}$ & $\begin{array}{l}0.489 * * * \\
(0.085)\end{array}$ \\
\hline Income Per capita ${ }_{t-1}$ & $\begin{array}{l}0.102 * * * \\
(0.015)\end{array}$ & $\begin{array}{l}0.106 * * * \\
(0.017)\end{array}$ & $\begin{array}{l}0.072 * * * \\
(0.010)\end{array}$ & $\begin{array}{l}0.010 \\
(0.035)\end{array}$ & $\begin{array}{c}-0.129 * \\
(0.076)\end{array}$ \\
\hline Hansen J Test & 0.14 & 0.51 & & & 0.26 \\
\hline Difference Hansen J Test & 0.21 & 0.59 & & & \\
\hline $\operatorname{AR}(1)$ Test & 0.00 & 0.00 & & & 0.00 \\
\hline AR (2) Test & 0.29 & 0.30 & & & 0.45 \\
\hline Number of Instruments & 66 & 22 & & & \\
\hline Observations & 889 & 889 & 945 & 945 & 838 \\
\hline Countries & 134 & 134 & 150 & 150 & 127 \\
\hline $\mathrm{R}$-squared & & & 0.73 & 0.80 & \\
\hline Source & \multicolumn{2}{|c|}{ Authors } & \multicolumn{3}{|c|}{ AJRY (2008) } \\
\hline
\end{tabular}

Note: * and ${ }^{* * *}$ represent the statistical significance at $10 \%$ and $1 \%$ level, respectively. Standard errors clustered at the country level are reported in parentheses. 
Table 4: Robustness Checks

\begin{tabular}{|c|c|c|c|c|c|c|c|c|}
\hline \multirow[t]{3}{*}{ DV is Democracy } & \multicolumn{8}{|c|}{ Freedom House Measure } \\
\hline & \multicolumn{8}{|c|}{ Estimation Method: System-GMM } \\
\hline & $(1)$ & $\begin{array}{l}\text { Balanced Panel } \\
\text { 1970-2000 } \\
(2)\end{array}$ & $\begin{array}{l}\text { Excluding } \\
\text { Former } \\
\text { Socialist } \\
\text { Countries } \\
(3)\end{array}$ & $\begin{array}{l}\text { Additional } \\
\text { Controls } 1 \\
\text { (4) }\end{array}$ & $\begin{array}{l}\text { Additional } \\
\text { Controls } 2 \\
\text { (5) }\end{array}$ & $\begin{array}{l}\text { IV: Past } \\
\text { Savings } \\
\text { Rate } \\
\text { (6) }\end{array}$ & $\begin{array}{l}\text { IV: } \\
\text { Predicted } \\
\text { Income } \\
(7)\end{array}$ & $\begin{array}{l}\text { Extending Data } \\
\text { to More Recent } \\
\text { Years } \\
(1950-2010) \\
(8)\end{array}$ \\
\hline Democracy $_{\mathrm{t}-1}$ & $\begin{array}{l}0.655 * * * \\
(0.084)\end{array}$ & $\begin{array}{c}0.565 * * * \\
(0.064)\end{array}$ & $\begin{array}{c}0.558 * * * \\
(0.060)\end{array}$ & $\begin{array}{c}0.559 * * * \\
(0.065)\end{array}$ & $\begin{array}{c}0.559 * * * \\
(0.065)\end{array}$ & $\begin{array}{c}0.582 * * * \\
(0.060)\end{array}$ & $\begin{array}{l}0.577 * * * \\
(0.060)\end{array}$ & $\begin{array}{c}0.657 * * * \\
(0.045)\end{array}$ \\
\hline Income Per Capita -1 & $\begin{array}{l}0.072 * * * \\
(0.020)\end{array}$ & $\begin{array}{l}0.114 * * * \\
(0.017)\end{array}$ & $\begin{array}{c}0.104 * * * \\
(0.015)\end{array}$ & $\begin{array}{c}0.061 * * * \\
(0.022)\end{array}$ & $\begin{array}{c}0.053 * \\
(0.028)\end{array}$ & $\begin{array}{c}0.088 * * * \\
(0.021)\end{array}$ & $\begin{array}{l}0.078 * * * \\
(0.026)\end{array}$ & $\begin{array}{c}0.057 * * * \\
(0.009)\end{array}$ \\
\hline Log Population t-1 & & & & $\begin{array}{c}-0.002 \\
(0.007)\end{array}$ & $\begin{array}{l}0.002 \\
(0.008)\end{array}$ & & & \\
\hline Education $_{\mathrm{t}-1}$ & & & & $\begin{array}{c}0.012 * * \\
(0.006)\end{array}$ & $\begin{array}{c}0.014 * \\
(0.007)\end{array}$ & & & \\
\hline Age Structure $\mathrm{t}_{\mathrm{t}-1}$ & & & & {$[0.10]$} & {$[0.02]$} & & & \\
\hline Urbanization & & & & & $\begin{array}{c}-0.001 \\
(0.001)\end{array}$ & & & \\
\hline Number of Previous & & & & & 0.011 & & & \\
\hline Democratic Breakdowns & & & & & $(0.007)$ & & & \\
\hline International Order & & & & & $\begin{array}{l}0.029 \\
(0.025)\end{array}$ & & & \\
\hline Growth Rate & & & & & $\begin{array}{c}-0.061 \\
(0.077)\end{array}$ & & & \\
\hline Hansen J Test & 0.08 & 0.06 & 0.19 & 0.44 & 0.07 & 0.13 & 0.21 & 0.09 \\
\hline Difference Hansen J Test & 0.90 & 0.02 & 0.23 & 0.19 & 0.38 & 0.92 & 0.33 & 0.46 \\
\hline AR (1) Test & 0.00 & 0.00 & 0.00 & 0.00 & 0.00 & 0.00 & 0.00 & 0.00 \\
\hline AR(2) Test & 0.32 & 0.38 & 0.27 & 0.88 & 0.89 & 0.43 & 0.33 & 0.57 \\
\hline Number of Instruments & 66 & 45 & 66 & 67 & 53 & 63 & 65 & 91 \\
\hline
\end{tabular}




\begin{tabular}{l|l|lcccc} 
Observations & 802 & 567 & 868 & 662 & 521 & 891 \\
Countries & 121 & 81 & 125 & 94 & 895 & 1403 \\
\hline Note: $* * * * * *$ & represent the statistical significance at $10 \%, 5 \%, 1 \%$ level, respectively. Standard errors clustered at the country level are reported in parentheses. DV denotes d
\end{tabular}

Note: $*, * * * *$ represent the statistical significance at $10 \%, 5 \%, 1 \%$ level, respectively. Standard errors clustered at the country level are reported in parentheses. DV denotes dependent variable. 


\section{Table 5: Different Time Intervals}

\begin{tabular}{|c|c|c|c|}
\hline & \multicolumn{3}{|c|}{$\begin{array}{l}\text { Dependent Variable is Democracy } \text { (Polity Measure) } \\
\text { Estimation Method: System-GMM } \\
5 \text { Year Interval } 10 \text { Year Interval } 25 \text { Year Interval } \\
\begin{array}{lll}(1) & (2) & (3)\end{array} \\
\end{array}$} \\
\hline Democracy $_{\mathrm{t}-1}$ & $\begin{array}{l}0.641 * * * \\
(0.041)\end{array}$ & $\begin{array}{l}0.450 * * * \\
(0.067)\end{array}$ & $\begin{array}{c}0.284 * * \\
(0.122)\end{array}$ \\
\hline Income Per Capitat-1 & $\begin{array}{l}0.068 * * * \\
(0.010) \\
\end{array}$ & $\begin{array}{c}0.103 * * * \\
(0.016)\end{array}$ & $\begin{array}{c}0.160 * * * \\
(0.052)\end{array}$ \\
\hline Hansen J Test & 1.00 & 1.00 & 0.32 \\
\hline Difference Hansen J Test & 1.00 & 1.00 & 0.76 \\
\hline AR (1) Test & 0.00 & 0.00 & 0.00 \\
\hline AR (2) Test & 0.99 & 1.00 & 0.49 \\
\hline Number of Instruments & 734 & 210 & 36 \\
\hline Observations & 1644 & 807 & 126 \\
\hline Countries & 151 & 130 & 42 \\
\hline
\end{tabular}

the country level are reported in parentheses. 
Table 6: Different Time Periods

\begin{tabular}{|c|c|c|c|c|c|}
\hline & \multicolumn{5}{|c|}{$\begin{array}{c}\text { Dependent Variable is Democracy }(\text { Polity Measure) } \\
\text { Estimation Method: System-GMM }\end{array}$} \\
\hline & $\begin{array}{l}1820-1849 \\
(1)\end{array}$ & $\begin{array}{l}1850-1920 \\
\text { (2) }\end{array}$ & $\begin{array}{l}\text { 1920-1944 } \\
\text { (3) }\end{array}$ & $\begin{array}{l}1945-1975 \\
\text { (4) }\end{array}$ & $\begin{array}{l}1976-2008 \\
\text { (5) }\end{array}$ \\
\hline Democracy $_{\mathrm{t}-1}$ & $\begin{array}{l}1.028 * * * \\
(0.031)\end{array}$ & $\begin{array}{l}0.883 * * * \\
(0.053)\end{array}$ & $\begin{array}{l}0.495 * * * \\
(0.154)\end{array}$ & $\begin{array}{l}0.527 * * * \\
(0.088)\end{array}$ & $\begin{array}{l}0.737 * * * \\
(0.042)\end{array}$ \\
\hline Income Per Capita ${ }_{\mathrm{t}-1}$ & $\begin{array}{l}0.017 \\
(0.035) \\
\end{array}$ & $\begin{array}{l}0.050^{* *} \\
(0.022)\end{array}$ & $\begin{array}{l}0.219 * * * \\
(0.074)\end{array}$ & $\begin{array}{l}0.135^{* * *} \\
(0.024)\end{array}$ & $\begin{array}{l}0.024 * * * \\
(0.009)\end{array}$ \\
\hline Hansen $\mathrm{J}$ Test & 1.00 & 1.00 & 0.34 & 0.28 & 0.00 \\
\hline Difference Hansen J Test & 1.00 & 1.00 & 0.26 & 0.64 & 0.03 \\
\hline AR(1) Test & 0.11 & 0.01 & 0.16 & 0.00 & 0.00 \\
\hline AR (2) Test & 0.48 & 0.46 & 0.05 & 0.55 & 0.85 \\
\hline Number of Instruments & 17 & 120 & 113 & 28 & 21 \\
\hline Observations & 24 & 242 & 43 & 397 & 518 \\
\hline Countries & 7 & 26 & 15 & 111 & 150 \\
\hline
\end{tabular}

Note: ${ }^{* *}$ and ${ }^{* * *}$ represent the statistical significance at $5 \%$ and $1 \%$ level, respectively. Standard errors clustered at the country level are reported in parentheses. 
Table 7: Differential Impacts across Countries with Different Initial Degrees of Democracy

\begin{tabular}{|c|c|}
\hline \multicolumn{2}{|c|}{ Dependent Variable is Democracy (Freedom House Measure) $^{2}$} \\
\hline & Estimation Method: System-GMM \\
\hline & (1) \\
\hline Democracy $\mathrm{t}_{-1}$ & $\begin{array}{l}0.655 * * * \\
(0.077)\end{array}$ \\
\hline Income Per Capitat ${ }_{\mathrm{t}-1} * \tau_{\mathrm{t}-1}$ & $\begin{array}{l}0.078 * * * \\
(0.011)\end{array}$ \\
\hline Income Per Capitat ${ }_{\mathrm{t}-1} *\left(1-\tau_{\mathrm{t}-1}\right)$ & $\begin{array}{l}0.080 * * * \\
(0.013)\end{array}$ \\
\hline Hansen $\mathrm{J}$ test & 0.08 \\
\hline Difference Hansen J Test & 0.05 \\
\hline AR (1) Test & 0.00 \\
\hline AR (2) Test & 0.27 \\
\hline Number of Instruments & 68 \\
\hline Observations & 896 \\
\hline Countries & 134 \\
\hline
\end{tabular}

Note: ${ }^{* *}$ represents the statistical significance at $1 \%$ level. Standard errors clustered at the country level are reported in parentheses.

$\tau_{t-1}$ is a dummy variable taking a value of 1 if democracy is below the sample mean and 0 otherwise. 
Figure 1: Effect of Income on Democracy: U.S. and Colombia.

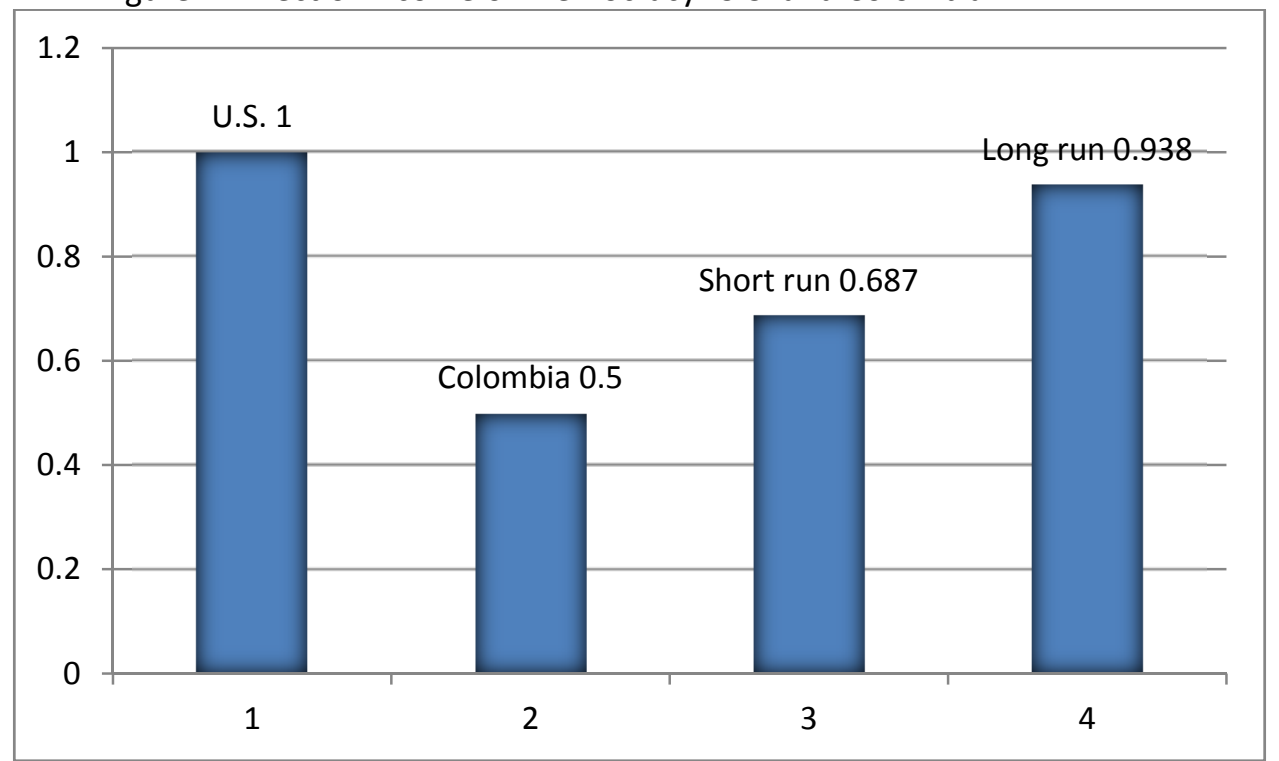

Note: The first pillar is the degree of democracy of U.S. in year 2000 (Freedom House measure). The second pillar is the degree of democracy of Colombia in year 2000 (Freedom House measure). The

third pillar is the short run degree of democracy of Colombia when the level of income per capita of

Colombia in year 2000 is raised to the level of income per capita of U.S. in year 2000. The fourth pillar is

the long run degree of democracy of Colombia when the level of income per capita of Colombia in year

2000 is raised to the level of income per capita of U.S. in year 2000. 
Appendix Table A: Robustness Checks, System-GMM with Collapsing Instruments

\begin{tabular}{|c|c|c|c|c|c|c|c|c|}
\hline \multirow[t]{3}{*}{ DV is Democracy } & Polity Measure & \multicolumn{7}{|c|}{ Freedom House Measure } \\
\hline & \multicolumn{8}{|c|}{ Estimation Method: System-GMM with Collapsing Instruments } \\
\hline & (1) & $\begin{array}{l}\text { Balanced } \\
\text { Pane1 } \\
\text { 1970-2000 } \\
(2)\end{array}$ & $\begin{array}{l}\text { Excluding } \\
\text { Former } \\
\text { Socialist } \\
\text { countries } \\
(3)\end{array}$ & $\begin{array}{l}\text { Additional } \\
\text { Controls } 1\end{array}$ & $\begin{array}{l}\text { Additional } \\
\text { Controls } 2\end{array}$ & $\begin{array}{l}\text { IV: Past } \\
\text { Savings } \\
\text { Rate } \\
\text { (6) }\end{array}$ & $\begin{array}{l}\text { IV: } \\
\text { Predicted } \\
\text { Income } \\
(7)\end{array}$ & $\begin{array}{l}\text { Extending Data } \\
\text { to More Recent } \\
\text { Years } \\
(1950-2010) \\
(8)\end{array}$ \\
\hline Democracy $_{\mathrm{t}-1}$ & $\begin{array}{c}0.660 * * * \\
(0.079)\end{array}$ & $\begin{array}{l}0.584 * * * \\
(0.078)\end{array}$ & $\begin{array}{c}0.542 * * * \\
(0.068)\end{array}$ & $\begin{array}{l}0.546 * * * \\
(0.073)\end{array}$ & $\begin{array}{l}0.570 * * * \\
(0.066)\end{array}$ & $\begin{array}{c}0.578 * * * \\
(0.068)\end{array}$ & $\begin{array}{l}0.565 * * * \\
(0.068)\end{array}$ & $\begin{array}{c}0.618 * * * \\
(0.056)\end{array}$ \\
\hline Income Per Capitat $\mathrm{t}_{-1}$ & $\begin{array}{l}0.071 * * * \\
(0.019)\end{array}$ & $\begin{array}{l}0.108 * * * \\
(0.020)\end{array}$ & $\begin{array}{l}0.108 * * * \\
(0.017)\end{array}$ & $\begin{array}{l}0.065 * * * \\
(0.022)\end{array}$ & $\begin{array}{c}0.053 * * \\
(0.026)\end{array}$ & $\begin{array}{l}0.084 * * * \\
(0.023)\end{array}$ & $\begin{array}{l}0.066 * \\
(0.037)\end{array}$ & $\begin{array}{l}0.063 * * * \\
(0.011)\end{array}$ \\
\hline Log Population ${ }_{t-1}$ & & & & $\begin{array}{l}-0.001 \\
(0.007)\end{array}$ & $\begin{array}{l}0.002 \\
(0.008)\end{array}$ & & & \\
\hline Education $_{\mathrm{t}-1}$ & & & & $\begin{array}{c}0.011 * \\
(0.006)\end{array}$ & $\begin{array}{c}0.013 * \\
(0.007)\end{array}$ & & & \\
\hline Age Structure $\mathrm{t}_{\mathrm{t}-1}$ & & & & {$[0.11]$} & {$[0.01]$} & & & \\
\hline Urbanization & & & & & $\begin{array}{l}-0.001 \\
(0.001)\end{array}$ & & & \\
\hline Number of Previous Democratic & & & & & 0.011 & & & \\
\hline Breakdowns & & & & & $(0.007)$ & & & \\
\hline International Order & & & & & $\begin{array}{l}0.029 \\
(0.025)\end{array}$ & & & \\
\hline Growth Rate & & & & & $\begin{array}{c}-0.061 \\
(0.077)\end{array}$ & & & \\
\hline Hansen J Test & 0.01 & 0.57 & 0.63 & 0.70 & 0.24 & 0.15 & 0.46 & 0.08 \\
\hline Difference Hansen J Test & 0.03 & 0.90 & 0.76 & 0.25 & 0.24 & 0.01 & 0.12 & 0.73 \\
\hline AR (1) Test & 0.00 & 0.00 & 0.00 & 0.00 & 0.00 & 0.00 & 0.00 & 0.00 \\
\hline AR (2) Test & 0.31 & 0.37 & 0.28 & 0.89 & 0.90 & 0.43 & 0.34 & 0.61 \\
\hline Number of Instruments & 22 & 18 & 22 & 27 & 27 & 20 & 21 & 26 \\
\hline
\end{tabular}




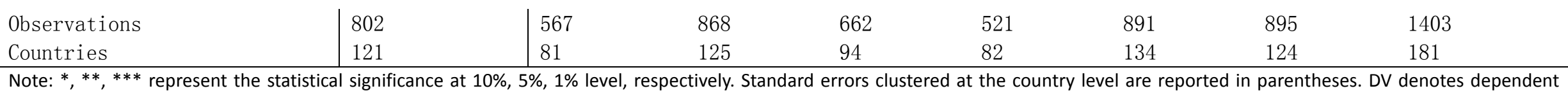

variable. 
Appendix Table B: System-GMM with Collapsing Instruments Estimation, Different Time Intervals and Different Time Periods

\begin{tabular}{|c|c|c|c|c|c|c|c|c|}
\hline & \multicolumn{8}{|c|}{ Dependent Variable is Democracy (Polity Measure) $^{\prime}$} \\
\hline & \multicolumn{3}{|c|}{ Different Time Intervals } & \multicolumn{5}{|c|}{ Different Time Periods } \\
\hline & \multicolumn{8}{|c|}{ Estimation Method: System-GMM with Collapsing Instruments } \\
\hline & $\begin{array}{l}5 \text { Year Interval } \\
(1)\end{array}$ & $\begin{array}{l}10 \text { Year Interval } \\
(2)\end{array}$ & $\begin{array}{l}25 \text { Year Interval } \\
(3)\end{array}$ & $\begin{array}{l}1820-1849 \\
(4)\end{array}$ & $\begin{array}{l}1850-1920 \\
(5)\end{array}$ & $\begin{array}{l}1920-1944 \\
(6)\end{array}$ & $\begin{array}{l}1945-1975 \\
(7)\end{array}$ & $\begin{array}{l}1976-2008 \\
(8)\end{array}$ \\
\hline Democracy $_{t-1}$ & $\begin{array}{l}0.628 * * * \\
(0.060)\end{array}$ & $\begin{array}{l}0.440 * * * \\
(0.080)\end{array}$ & $\begin{array}{l}0.412 * * * \\
(0.147)\end{array}$ & $\begin{array}{l}1.041^{* * *} \\
(0.042)\end{array}$ & $\begin{array}{l}1.060 * * * \\
(0.093)\end{array}$ & $\begin{array}{l}0.621 * * * \\
(0.132)\end{array}$ & $\begin{array}{l}0.486 * * * \\
(0.113)\end{array}$ & $\begin{array}{l}0.675^{* * *} \\
(0.054)\end{array}$ \\
\hline Income Per Capitat-1 & $\begin{array}{l}0.072 * * * \\
(0.013) \\
\end{array}$ & $\begin{array}{l}0.106 * * * \\
(0.019) \\
\end{array}$ & $\begin{array}{l}0.108 * \\
(0.061) \\
\end{array}$ & $\begin{array}{l}0.016 \\
(0.034) \\
\end{array}$ & $\begin{array}{l}0.0002 \\
(0.032) \\
\end{array}$ & $\begin{array}{l}0.176 * * * \\
(0.067)\end{array}$ & $\begin{array}{l}0.146^{* * *} \\
(0.030)\end{array}$ & $\begin{array}{l}0.032 * * * \\
(0.011)\end{array}$ \\
\hline Hansen J Test & 0.17 & 0.06 & 0.04 & 1.00 & 0.59 & 0.12 & 0.89 & 0.01 \\
\hline Difference Hansen J Test & 0.39 & 0.63 & 0.04 & 1.00 & 1.00 & 0.16 & 0.87 & 0.26 \\
\hline AR(1) Test & 0.00 & 0.00 & 0.00 & 0.12 & 0.01 & 0.07 & 0.00 & 0.00 \\
\hline AR (2) Test & 1.00 & 0.06 & 0.64 & 0.48 & 0.53 & 0.05 & 0.54 & 0.84 \\
\hline Number of Instruments & 76 & 40 & 16 & 12 & 30 & 10 & 14 & 12 \\
\hline Observations & 1644 & 807 & 126 & 24 & 242 & 113 & 397 & 518 \\
\hline Countries & 151 & 130 & 42 & 7 & 26 & 43 & 111 & 150 \\
\hline
\end{tabular}

Note: $*$ and $* * *$ represent the statistical significance at $10 \%$ and $1 \%$ level, respectively. Standard errors clustered at the country level are reported in parentheses. 
Appendix Table C: System-GMM (with Collapsing Instruments) Estimation,

Differential Impacts across Countries with Different Initial Degrees of Democracy

Dependent Variable is Democracyt (Freedom House Measure)

\begin{tabular}{l|l}
\hline \multicolumn{2}{c}{ Estimation Method: System-GMM with Collapsing Instruments } \\
\hline \multicolumn{2}{c}{$(1)$} \\
\hline Democracy $_{\mathrm{t}-1}$ & $0.584 * * *$ \\
& $(0.093)$ \\
Income Per Capita $\mathrm{t}_{-1} * \tau_{\mathrm{t}-1}$ & $0.084 * * *$ \\
& $(0.012)$ \\
Income Per Capitat ${ }_{\mathrm{t}-1}\left(1-\tau_{\mathrm{t}-1}\right)$ & $0.090 * * *$ \\
& $(0.015)$ \\
\hline Hansen J Test & 0.36 \\
Difference Hansen J Test & 0.14 \\
AR(1) Test & 0.00 \\
AR (2) Test & 0.28 \\
Number of Instruments & 24 \\
Observations & 896 \\
Countries & 134 \\
\hline
\end{tabular}

Note: $* * *$ represents the statistical significance at $1 \%$ level. Standard errors clustered at the country level are reported in parentheses.

$\tau_{t-1}$ is a dummy variable taking a value of 1 if democracy is below the sample mean and 0 otherwise. 